\title{
Effect of zeolite on the growth and yield of broccoli in the dry
}

\section{season}

\author{
Karistsapol Nooprom*, Pongsak Mansuriwong, Supakracha Apiratikorn \\ Faculty of Agricultural Technology, Songkhla Rajabhat University, Muang Songkhla District, Songkhla Province 90000, Thailand \\ *Email: abhichard_n@hotmail.co.th
}

\section{OPEN ACCESS}

\section{ARTICLE HISTORY}

Received: 06 July 2021

Accepted: 17 September 2021

Available online

Version 1.0 (Early Access): 05 December 2021 Version 2.0:01 January 2022

\section{Check for updates}

\section{Additional information}

Peer review: Publisher thanks Sectional Editor and the other anonymous reviewers for their contribution to the peer review of this work.

Reprints \& permissions information is available at https://horizonepublishing.com/ journals/index.php/PST/open_access_policy

Publisher's Note: Horizon e-Publishing Group remains neutral with regard to jurisdictional claims in published maps and institutional affiliations.

Indexing: Plant Science Today, published by Horizon e-Publishing Group, is covered by Scopus, Web of Science, BIOSIS Previews, Clarivate Analytics, etc. See https:// horizonepublishing.com/journals/index.php/ PST/indexing_abstracting

Copyright: () The Author(s). This is an openaccess article distributed under the terms of the Creative Commons Attribution License, which permits unrestricted use, distribution and reproduction in any medium, provided the original author and source are credited (https://creativecommons.org/licenses/ by/4.0/)

\section{CITE THIS ARTICLE}

Nooprom K, Mansuriwong P, Apiratikorn S. Effect of zeolite on the growth and yield of broccoli in the dry season. Plant Science Today. 2022;9(1):76-80.

https://doi.org/10.14719/pst.1041

\begin{abstract}
Broccoli (Brassica oleracea var. italica Plenck) growth and yield are impacted in warmer climates, especially during the dry season. Broccoli gives low yield and quality although it is heat-tolerant cultivars. Zeolite is an organic material recognized as suitable for dry season plant growth because it can adsorb cations, nutrients and water and release on demand from the plant. Application of zeolite in the soil may improve broccoli growth and yield during the dry season. The trial preparation followed a randomized complete block design (RCBD) with four replications involving five amounts of zeolite at $0,1.56,3.12,4.68$ and $6.24 \mathrm{t} \mathrm{ha}^{-1}$ using broccoli cultivar 'Top Green'. Results showed that zeolite applications of 4.68 and $6.24 \mathrm{t} \mathrm{ha}^{-1}$ improved growth and yield parameters including plant width, stem diameter, time to $50 \%$ flowering and harvest, head diameter and head weight better than the other treatments. Application of zeolite at $6.24 \mathrm{t} \mathrm{ha}^{-1}$ gave high total broccoli yield of $8.45 \mathrm{tha}^{-1}$ but not significantly different $(p \leq 0.05)$ from $4.68 \mathrm{t} \mathrm{ha}^{-1}$ that gave $7.89 \mathrm{t} \mathrm{ha}^{-1}$. Results indicated that application of zeolite at $4.68 \mathrm{t} \mathrm{ha}^{-1}$ was optimal for reducing drought stress and enhancing effective growth and yield of broccoli.
\end{abstract}

\section{Keywords \\ Broccoli, Zeolite, Drought stress}

\section{Introduction}

Broccoli belongs to the Brassicaceae family which consists of the Cole crops viz., cauliflower, cabbage and kale (1) that originated from the Mediterranean region (2). Broccoli is a popular vegetable that is cultivated in many countries including Australia, New Zealand, Japan, Canada, Germany, the Netherlands, the United States of America and Thailand (3). Broccoli has high nutritional value and many health benefits from contained antioxidant substances that ameliorate the onset of some types of cancer $(4,5)$. In Thailand, broccoli cultivation has recently expanded, with increased production to satisfy the requirements of domestic consumers(6). The most suitable temperature for broccoli cultivation is between 10 and $20^{\circ} \mathrm{C}$ (1). Therefore, in Thailand, broccoliis generally cultivated in northern areas where temperatures are lower or northeastern regions during the cool season $(3,7)$. Southern areas are humid with no cool season and unsuitable for broccoli growth, while local consumers generate high product demand (8).To meet consumption demands in the south, heat-tolerant broccoli cultivars such as 'Green Queen', 'Yok Kheo' and 'Top Green' have been developed as better adapted to humid tropical weather (9). 
Drought stress is one of the most important environmental factors that influence plant cultivation in the dry season (10). Drought causes stress in plants because the soil cannot accumulate enough moisture necessary for plant growth (11). Broccoli is most sensitive to drought stress (12) causing decreasing growth and yield in the dry season $(6,13)$. The shading technology under greenhouse is recommended for broccoli farmers. It was reported that broccoli cultivated under shading in southern Thai greenhouses during the dry season showed higher growth and yield than in open fields (14). However, the high costs for greenhouse construction are prohibitive for southern farmers. It was already reported (15) that addition of zeolite to the soil improved plant growth and yield under drought stress for canola, wheat, amaranthus (16) and sorghum (11). Reports are also on the zeolite application improved shoot yield and follow oil yield of peppermint in the dry season (17). Zeolite also contains macronutrients and micronutrients including $\mathrm{N}, \mathrm{K}, \mathrm{Ca}, \mathrm{Mg}, \mathrm{Zn}, \mathrm{Mn}$ and $\mathrm{Cu}$ (18), which counterbalance the loss of nutrients in the soil (19). The influence of zeolite in improving dry season growth and yield of broccoli in Southern Thailand was investigated.

\section{Materials and Methods}

\section{Plant material and experimental}

Broccoli cultivar 'Top Green' was selected for this experiment as a heat-tolerant cultivar that can produce high yield in Southern Thailand (8). A randomized complete block design using four replications was used to carry out the experiment at Songkhla Rajabhat University, Muang Songkhla District, Songkhla Province, Thailand, latitude $7^{\circ}$ 12 ' 27 " N, longitude $100^{\circ} 35^{\prime} 48^{\prime \prime} \mathrm{E}$ and altitude $4 \mathrm{~m}$ above sea level (Fig. 1) (20) between March and May, 2016. Experimental therapies comprised zeolite addition at five amounts as 0 (control), 1.56, 3.12, 4.68 and $6.24 \mathrm{t} \mathrm{ha}^{-1}(21)$. The soil was prepared for planting by plowing, disking and leveling. Raised-beds with plot size of $1.0 \mathrm{~m}$ width, $5.0 \mathrm{~m}$ length and $0.20 \mathrm{~m}$ height were manually prepared. One week before broccoli planting, each treatment of zeolite was incorporated into the plots (22). One-month-old broccoli seedlings were transplanted into the plots with plant and row spacing of 0.30 and $0.60 \mathrm{~m}$ respectively. Each plot consisted of 2 rows with 16 plants in each row. Broccoli plants were watered frequently using a sprinkler in the morning and the afternoon, excluding rainy days. Fertilizer $21 \mathrm{~N}-0 \mathrm{P}-0 \mathrm{~K}$ was applied three times at 2, 3 and 4 weeks after transplantation, while fertilizer $15 \mathrm{~N}-6.5 \mathrm{P}-12.5 \mathrm{~K}$ was used 5 and 6 weeks after transplantation. At 2 and 4 weeks after transplantation, the plots were weeded using a hand hoe (7).

\section{Data collection}

Seedling survival rate at 30 days after transplanting (\%) was determined. Plant height $(\mathrm{cm})$ was measured for 10 random plants in the plot by taking the distance from the soil surface to the longest top leaf, plant width $(\mathrm{cm})$ was measured for 10 random plants in the plot by taking the distance from the longest leaf on one side to the other

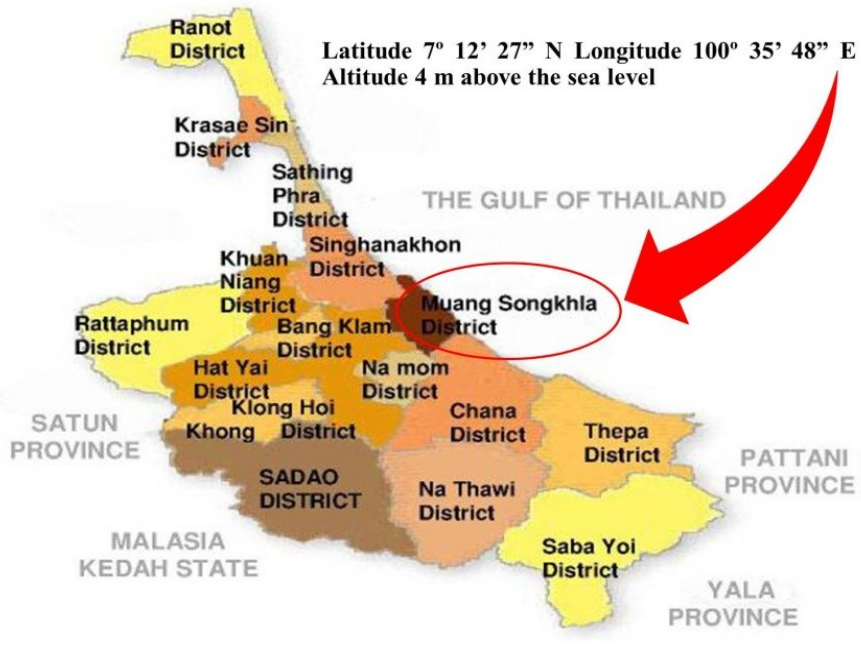

Fig. 1. District map of Songkhla Province showing the study area (20) .

longest one on the opposite side and stem diameter $(\mathrm{cm})$ was measured for ten random plants in the plot using a digital caliper (Insize series 1108, U.S.A.) at time to 50\% flowering stage. The number of days from transplanting to the beginning of $50 \%$ flowering and harvest (DAT) was recorded. Other data were recorded from harvested plants in the plot: stalk length $(\mathrm{cm})$, head diameter $(\mathrm{cm})$, head weight $(\mathrm{g})$ and total yield $\left(\mathrm{t} \mathrm{ha} \mathrm{a}^{-1}\right)(7)$. Soil samples in each plot were extracted at a depth of $0-20 \mathrm{~cm}$ and evaluated for total nitrogen (total $N$ ), organic matter (OM), available phosphorus (avail. P), available potassium (avail. K), available calcium (avail. Ca), available magnesium (avail. Mg) and $\mathrm{pH}$.

\section{Statistical analysis and experimental}

Data were assessed using analysis of variance (ANOVA), with means determined utilizing Duncan's Multiple Range Test (DMRT) with $p \leq 0.05$.

\section{Results}

\section{Growth parameters}

Application of zeolite did not significantly affect broccoli seedling survival (Fig. 2A) and height compared to the control, with values of 72.65 to $82.02 \%$ and 42.09 to $44.76 \mathrm{~cm}$ respectively. On the other hand, zeolite application at all levels significantly increased plant width 60.61 to $65.31 \mathrm{~cm}$ compared with the control at $58.48 \mathrm{~cm}$. Highest stem diameter at $4.85 \mathrm{~cm}$ was obtained from application of zeolite at $6.24 \mathrm{t} \mathrm{ha}^{-1}$, followed by $4.68,3.12$ and $1.56 \mathrm{t} \mathrm{ha}^{-1}$ with stem diameter of 4.26 to $4.44 \mathrm{~cm}$, whereas lowest stem diameter was obtained from the control at $4.04 \mathrm{~cm}$ (Fig. 2B). Earliest times to $50 \%$ flowering and harvest were obtained from applications of 4.68 and $6.24 \mathrm{t} \mathrm{ha}^{-1}$ of zeolite, with values of 41.50 to 41.75 DAT and 51.75 to 52.00 DAT respectively. The most recent periods to $50 \%$ flowering and harvest were gained from 1.56 and $3.12 \mathrm{t} \mathrm{ha}^{-1}$ zeolite applications and control with values of 45.50 to 45.87 DAT and 55.50 to 56.37 DAT respectively (Fig. 2C).

\section{Yield parameters}

All zeolite application levels did not significantly affect broccoli stalk length compared with the control (Fig. 3A), 
with values of 36.88 to $40.01 \mathrm{~cm}$. However, zeolite treat- nutrient release (25) This improved plant growth under waments significantly affected head diameter, head weight ter deficit stress (24). Broccoli with added zeolite in the soil and total yield. Highest head diameter was obtained from produced higher head diameter, head weight and total $6.24 \mathrm{t} \mathrm{ha}^{-1}$ zeolite application at $13.25 \mathrm{~cm}$, which was only yield than the control. Similar results were reported in carslightly dissimilar $(p \leq 0.05)$ from the $4.68 \mathrm{t} \mathrm{ha}^{-1}$ zeolite appli- rots, cowpea, eggplant and potatoes grown in soil mixed cation at $13.07 \mathrm{~cm}$. Lowest head diameter was obtained with zeolite, with significantly increased yield compared from the control, 1.56 and $3.12 \mathrm{tha}^{-1}$ of zeolite applications with the control; $5 \mathrm{t} \mathrm{ha-1}$ of zeolite application yielded the with values of 10.53 to $11.08 \mathrm{~cm}$ (Fig. 3A). Highest head best results for these crop cultivations (18). Moreover, weight was obtained from 4.68 and $6.24 \mathrm{t} \mathrm{ha}^{-1}$ zeolite appli- applications of 4 to $8 \mathrm{t}$ ha-1 zeolite significantly increased cations with values of 268.93 and $282.64 \mathrm{~g}$ respectively that wheat, eggplant and apple crops by $13-15 \%, 19-55 \%$ and 13 were not significantly different $(p \leq 0.05)$, followed by $3.12-38 \%$ respectively (26) because zeolite boosted the accessiand $1.56 \mathrm{t} \mathrm{ha}^{-1}$ zeolite applications. Lowest head weight was bility to important nutrient elements such as nitrogen, obtained from the control at $225.18 \mathrm{~g}$ (Fig. 3B). Highest total phosphorus, potassium, calcium, magnesium and micronuyield was obtained from $6.24 \mathrm{t} \mathrm{ha}^{-1}$ of zeolite application trients was the main factors for plant growth (27). Zeolite with a value of $8.45 \mathrm{t} \mathrm{ha}^{-1}$, which was only slightly dissimilar retains nutrients in the root zone that are then used by $(p \leq 0.05)$ to $4.68 \mathrm{t} \mathrm{ha}^{-1}$ zeolite application, giving a yield of plants when required $(28,29)$. Positive effects of zeolite $7.84 \mathrm{t} \mathrm{ha}^{-1}$. Lowest total yield was obtained from the control application on plant growth and yield were related to inat $6.51 \mathrm{t} \mathrm{ha}^{-1}$, which was only slightly dissimilar $(\mathrm{p} \leq 0.05)$ to creased increments of soil nitrogen efficiency by 10 to $22 \%$ 1.56 and $3.12 \mathrm{t} \mathrm{ha}^{-1}$ zeolite applications, with yields of 6.88 and prevention of nitrogen leaching by 86 to $99 \%$ (30, 31). to $7.11 \mathrm{t} \mathrm{ha}^{-1}$ (Fig. 3C).

These findings concurred with analysis results of soil properties in the experimental plots, as shown in Table 1.

\section{Discussion}

Zeolite application promoted higher growth parameters of

\section{Conclusion}

broccoli grown in the dry season than the control for plant Adding zeolite to the soil had a significantly positive effect width, stem diameter, time to 50\% flowering and time to on growth and yield of broccoli grown in the dry season. $50 \%$ harvest. Similar results were reported in canola (15) Utilization of $4.68 \mathrm{t} \mathrm{ha}^{-1}$ of zeolite was recommended for and soybean (23). This occurred because zeolite decreased farmers because this improved effective growth and yield electrolyte leakage in plants (24) and increased soil reten- compared with other treatments. tion and water absorption to $100 \%$ in dry soils with slow
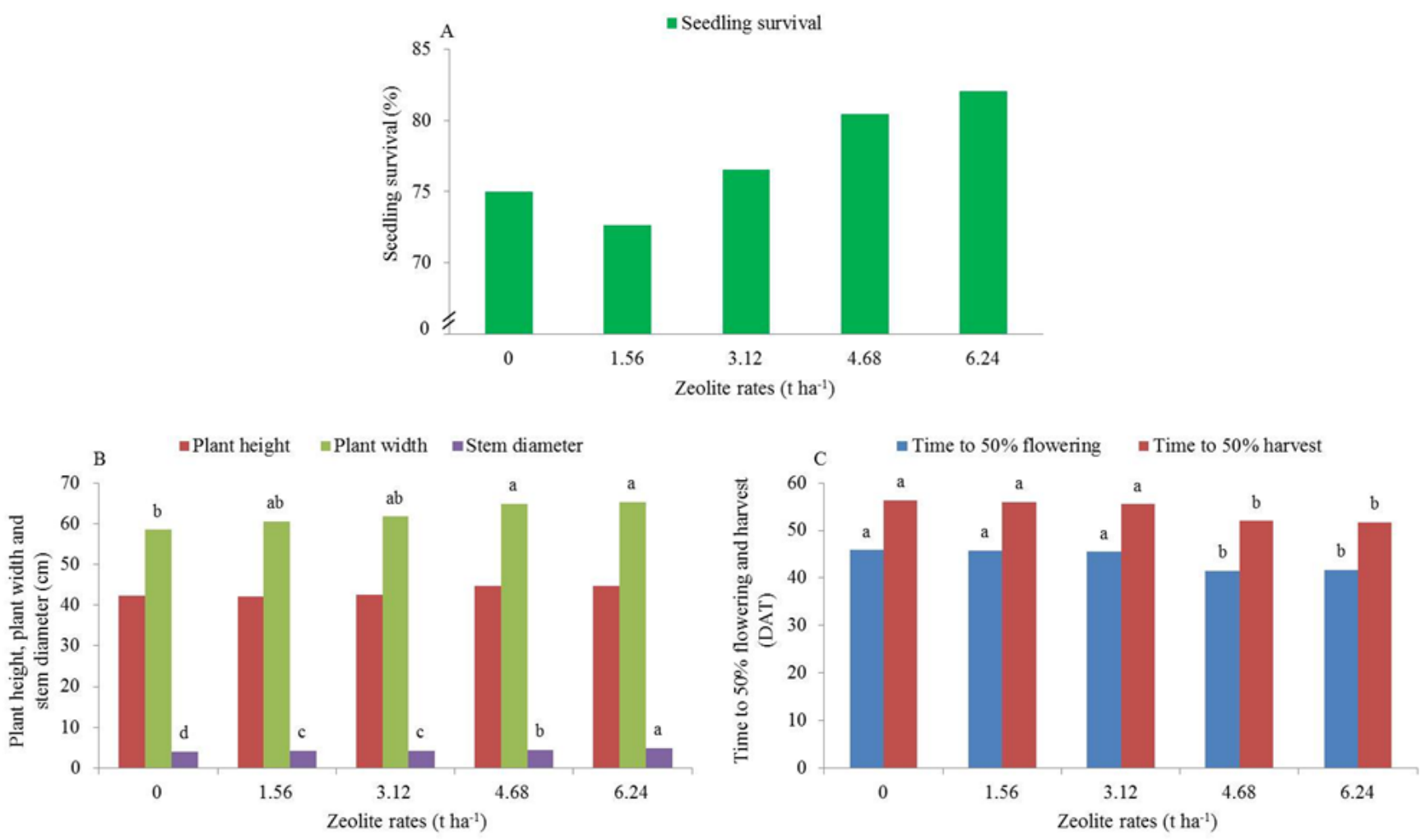

DAT $=$ Days after transplanting

Means sharing same letters are not significantly different at $p \leq 0.05$ by DMRT

Fig. 2. Growth parameters of broccoli with different rates of added zeolite. 

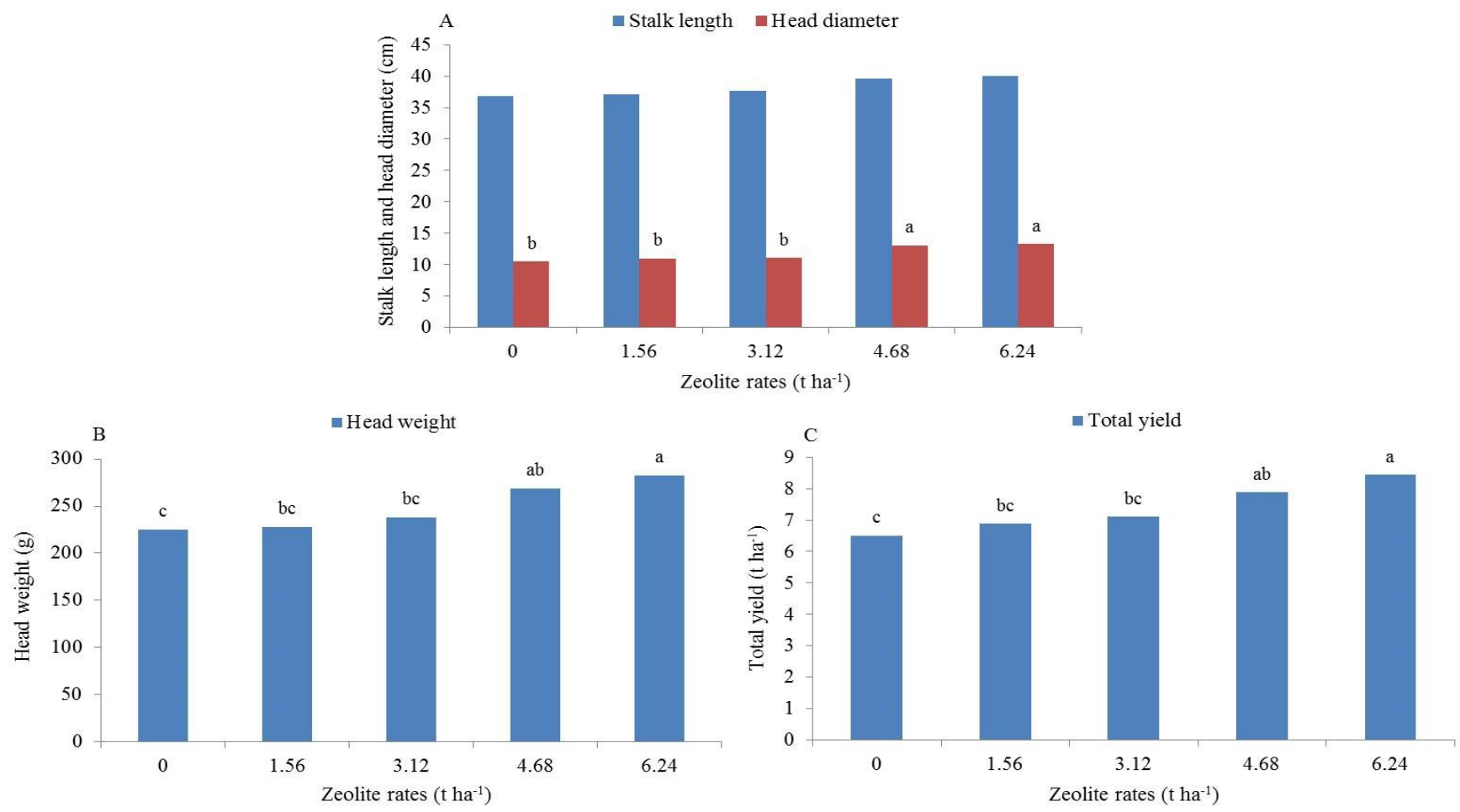

Means sharing same letters are not significantly different at $p \leq 0.05$ by DMRT

Fig. 3. Yield parameters of broccoli with different rates of added zeolite.

\section{Acknowledgements}

The authors would like to thank the Faculty of Agricultural Technology, Songkhla Rajabhat University, Muang Songkhla District, Songkhla Province, Thailand for support by providing the experimental equipment and access to the field site.

\section{Compliance with ethical standards}

Conflict of interest: The authors do not have any conflict of interests to declare.

Ethical issues: None.

\section{References}

1. Decoteau DR. Vegetable crops. New Jersey. The United States of America: Prentice Hall; 2000.

2. Ouda BA, Mahadeen AY. Effect of fertilizers on growth, yield, yield components, quality and certain nutrient content in broccoli (Brassica oleracea) [Internet]. 2008 [cited 2020 Oct 14];10(6):627-

\section{Available from: https://th.city/mrA3}

3. Nooprom K. Broccoli cultivation in warmer climates. In: Juurlink $\mathrm{BHJ}$, (eds). Broccoli: cultivation, nutritional properties and effects on health. New York: Nova Science; 2016. P 251-61.

4. Al-jaf HI. Growth and yield of broccoli (Brassica oleracea L. var. corato) as affected by humic acid application. J Plant Production, Mansoura Univ [Internet]. 2018 [cited 2020 Sep 12];9:739-41. https://dx.doi.org/10.21608/jpp.2018.36398

5. Erken O, Kuzucu CO, Cakir R. Impact of different water supply levels on yield and biochemical ingredients in broccoli [Internet]. 2013 [cited 2020 Sep 12];19(5):1009-17. Available from: https:// th.city/EMxSZ

6. Nooprom K, Santipracha Q. Growth and yield of broccoli planted year round in Songkhla province, Thailand. Res J App Sc Eng Technol [Internet]. 2014 [cited 2020 Sep 6];7(19): 4157-61. http:// dx.doi.org/10.19026/rjaset.7.781

7. Nooprom K, Santipracha Q, Te-chato S. Growth and yield of broccoli under different rain protectors during the rainy season in Songkhla province, southern Thailand [Internet]. 2014 [cited 2020 Sep 12];48(1):1-8. Available from: https://th.city/FSnS

Table 1. Experimental soil properties

\begin{tabular}{lrrrrrl}
\hline \multirow{2}{*}{ Soil property } & \multicolumn{5}{c}{ Addition of zeolite to the soil (t ha-1) } & Analysis method \\
\cline { 2 - 5 } & $\mathbf{0}$ & $\mathbf{1 . 5 6}$ & $\mathbf{3 . 1 2}$ & $\mathbf{4 . 6 8}$ & $\mathbf{6 . 2 4}$ & \\
\hline Total N & 0.11 & 0.13 & 0.15 & 0.15 & 0.17 & McKenzie method (\%) \\
OM & 2.52 & 2.56 & 2.61 & 2.70 & 2.74 & Walkley-Black method (\%) \\
Avail. P & 158.12 & 162.66 & 172.65 & 185.41 & 194.84 & Bray II (mg/kg) \\
Avail. K & 254.11 & 268.66 & 275.09 & 286.74 & 336.41 & $\mathrm{NH}_{4} \mathrm{OAc} \mathrm{extract}(\mathrm{mg} / \mathrm{kg})$ \\
Avail. Ca & 1743.90 & 1854.70 & 1916.96 & 2334.33 & 2942.88 & $\mathrm{NH}_{4} \mathrm{OAc}$ extract $(\mathrm{mg} / \mathrm{kg})$ \\
Avail. Mg & 245.77 & 264.32 & 266.62 & 284.11 & 341.72 & $\mathrm{NH}_{4} \mathrm{OAc}$ extract $(\mathrm{mg} / \mathrm{kg})$ \\
pH $\left(\mathrm{H}_{2} \mathrm{O}\right)$ & 6.42 & 7.16 & 7.33 & 7.43 & 7.52 & $\mathrm{pH}$ meter method \\
\hline
\end{tabular}


8. Nooprom K, Santipracha Q. Growth and yield of 7 early varieties of broccoli in Songkhla province [Internet]. 2011 [cited 2020 Aug 5];29(2):54-61. Available from: https://1th.me/Inubr

9. The United States of America. Patent and Trademark Office. Heat tolerant broccoli [Internet].Virginia: The office; 2004 [cited 2021 April 8]. Available from: https://th.city/IU4Y

10. Karimzadeh AK, Ghorbanpour M, Marefatzadeh KM. Influence of drought stress, biofertilizers and zeolite on morphological traits and essential oil constituents in Dracocephalum moldavica L. [Internet]. 2018 [cited 2020 Aug 5];17(67):91-112. Available from: https://th.city/X1KW0

11. Nasri M, Khalatbari M. Investigation physiological and biochemical characteristics of Sorghum (Sorghum bicolor L. var. kimia) affected zeolite consumption under water deficit situation [Internet]. 2018 [cited 2020 Sep 12];4(1):17-32. Available from: https://th.city/VPUK

12. Maurer AR. Response of broccoli to five soil water regimes. Can J Plant Sci [Internet]. 1976 [cited 2020 Sep 12];56(4):953-59. https://doi.org/10.4141/cjps76-154

13. Singh VP, Prasad VM, Deepanshu. Effect of sowing dates on growth and yield of broccoli (Brassica oleracea var. italica). Plant Archives [Internet]. 2017 [cited 2020 Aug 5];17(2):1063-70. http:// dx.doi.org/10.3923/ajps.2004.167.169

14. Nooprom K, Santipracha Q, Te-Chato S. Effect of shading and varieties on the growth and yield of broccoli during the dry season in southern Thailand [Internet]. 2013 [cited 2020 Sep 12];3 (2):111-15. Available from: https://th.city/2Ysvnd

15. Zahedi H, Rad AHS, Moghadam HRT. Effects of zeolite and selenium applications on some agronomic traits of three canola cultivars under drought stress. Pesqui Agropecu Trop [Internet]. 2011 [cited 2020 Sep 12];41(2):179-85. https://doi.org/10.5216/ pat.v41i2.9554

16. Karami S, Hadi H, Tajbaksh M, Modarres-Sanavy SAM. Effect of zeolite on nitrogen use efficiency and physiological and biomass traits of amaranth (Amaranthus hypochondriacus) under waterdeficit stress conditions. J Soil Sci Plant Nutr [Internet]. 2020 [cited 2020 Sep 12];20(1):1427-41. https://doi.org/10.1007/ s42729-020-00223-z

17. Ghanbari M, Ariafar S. The effects of water deficit and zeolite application on growth traits and oil yield of medicinal peppermint (Mentha piperita L.) [Internet].2013 [cited 2020 Oct 14];3 (1):32-39. Available from: https://th.city/JxiZWH

18. Ozbahce A, Tari AF, Gönülal E, Simsekli N, Padem H. The effect of zeolite applications on yield components and nutrient uptake of common bean under water stress. Arch Agron. Soil Sci [Internet]. 2015 [cited 2020 Oct 14];61(5):615-26. https:// doi.org/10.1080/03650340. 2014.946021

19. Milosevic T, Milosevic N. The effect of zeolite, organic and inorganic fertilizers on soil chemical properties, growth and biomass yield of apple trees. Plant Soil Environ [Internet]. 2009 [cited 2020 Oct 14];55(12):528-35. https://doi.org/10.17221/107/2009PSE
20. Wongboonsin P. Trafficking for sexual exploitation into sadao, Songkhla Province. In: Wongboonsin P, (eds). Trafficking for Sexual Exploitation into southern Thailand. Bangkok: Research Institute on Contemporary Southeast Asia; 2018. P 14-25.

21. Nooprom K, Santipracha Q. Effects of planting dates and varieties on growth and yield of broccoli during rainy season. AJABS [Internet] 2013[cited 2020 Oct 14];8(4):357-61. https:// doi.org/10.3844/ajabssp.2013.357.361

22. Hazrati S, Tahmasebi-Sarvestani Z, Mokhtassi-Bidgoli A. Effects of zeolite and water stress on growth, yield and chemical compositions of Aloe vera L. Agric Water Manag [Internet]. 2017 [cited 2020 Oct 14];181(2017): 66-72. http://dx.doi.org/10.1007/ s42729-020-00223-z

23. Nozari R, Moghadam HRT, Zahedi H. Effect of cattle manure and zeolite applications on physiological and biochemical changes in soybean (Glycine max L. Merr.) grown under water deficit stress. Revista Científica UDO Agrícola [Internet]. 2013 [cited 2020 Oct 14];13(1):76-84. http://dx.doi.org/10.13140/RG.2.1.4409.2648

24. Siringam K, Effect of drought stress on electrolyte leakage, photosynthetic pigment concentrations, proline content and growth of rice (Oryza sativa L.). TJST [Internet] 2016 [cited 2020 Oct 14];4 (2):133-46. https://doi.org/10.14456/tjst.2015.21

25. Abdel-Hassan S, Rali AMA. Effect of zeolite on some physical properties of wheat plant growth (Triticum aestivum L.) [Internet].2018 [cited 2020 Oct 14];18(2):2641-48. Available from: https://th.city/80x8

26. Li J., Wee C, Sohn B. Effect of ammonium- and potassium-loaded zeolite on kale (Brassica alboglabra) growth and soil property. Am J Plant Sci [Internet]. 2013 [cited 2020 Oct 14];4(10):1976-82. http://dx.doi.org/10.4236/ajps.2013.410245

27. Mahmoodabadi MR, Ronaghi A, Khayyat M, Hadarbadi G. Effects of zeolite and cadmium on growth and chemical composition of soybean (Glycine max L.) [Internet]. 2009 [cited 2020 Oct 14];10 (3):515-21.Available from: https://th.city/FSnS

28. Polat $E$, Karaca M, Demir H, Onus AN. Use of natural zeolite (clinoptilolite) in agriculture [Internet]. 2004 [cited 2020 Oct 14];12:183-89. Available from: https://th.city/Qw8o

29. Sangeetha C, Baskar P. Zeolite and its potential uses in agriculture: a critical review. Agric Rev [Internet]. 2016 [cited 2020 Oct 14];37(2):101-08. http://dx.doi.org/10.18805/ar.v0iof.9627

30. Abdi G, Khosh-Khui M, Eshghi S. Effects of natural zeolite on growth and flowering of strawberry (Fragaria $\times$ ananssa Duch.). Int J Agric Res [Internet] 2006 [cited 2020 Oct 14];1(4):384-89. https://dx.doi.org/10.3923/ijar.2006.384.389

31. Zahdei H, Noormohammadi G, Rad AHS, Habibi D, Boojar MMA. Effect of zeolite and foliar application of selenium on growth, yield and yield component of three canola cultivar under conditions of late season drought stress. Not Sci Biol [Internet] 2009 [cited 2020 Oct 14];1:73-80. https://doi.org/10.15835/nsb113500 